Printed by: serliw@ petra.ac.id. Printing is for personal, private use only. No part of this book may be reproduced or transmitted without publisher's prior permission. Violators will be prosecuted.

\title{
The effect of online promotion and travel motivation on intention to travel to ecotourism destinations in Indonesia: The role of destination image as a mediating variable
}

\author{
S.F. Mulianto, H. Semuel \& S. Wijaya \\ Faculty of Business and Economics, Petra Christian University, Surabaya, Indonesia
}

\begin{abstract}
Ecotourism is special interest tourism that the Indonesian government has developed and promoted as a means to attract more responsible tourists to visit the country. Promotion strategy has been undertaken using offline and online platforms to enhance the image of Indonesia as a worth-taking eco-tourism destination in the world. This study aimed to examine the effect of online promotion through various digital platforms, which play as an external stimulus, and travel motivation as an internal tourist's driver on tourists' destination image and travel intention to eco-tourism destinations in Indonesia. A survey was completed to 319 respondents who would like to travel to any eco-tourism destinations in Indonesia. The results showed that both online promotion and travel motivation directly affect tourists' intention to visit eco-tourism destinations in Indonesia. Meanwhile, the image held in tourists' minds about the destination had played as a significant mediating variable of the roles of online promotion and motivation in influencing tourists' travel intention.
\end{abstract}

\section{INTRODUCTION}

In recent years, sustainability has become one of the major foci when developing tourism in destinations. According to Weaver (2001), sustainable tourism and eco-tourism concept is viewed as persevering the natural environment and community, increasing welfare, as well as providing education to local communities. Eco-tourism is a form of responsible travel to natural areas that conserves the environment, sustains the well-being of the local people, and incorporates interpretation and education/(Lai, 2013). The change in tourism trends from general tourism to nature tourism can be used to educate tourist about the importance of protecting and respecting nature, as well as Indonesian culture. With its rich natural biodiversity, Indonesia has played an important role in the world's environmental conservation (Ramjdal, 2018). Eco-tourism, therefore, is special interest tourism that the Indonesian government has developed and promoted as a means to attract more responsible tourists to visit the country.

Promotion strategy has been undertaken using both offline and online platforms to enhance the image of Indonesia as a worth-taking eco-tourism destination in the world. Indonesia's tourism has been promoted online by the Indonesian government to overseas tourist with its website of Wonderful Indonesia since 2011 (Mandiri, 2016). Donohoe and Needham (2008) argue that online promotion is the most important marketing tool replacing traditional methods. Specifically, online promotion through social media can be seen through Instagram, Facebook, and other social networks (Chu \& Luckanavani, 2018). The online promotion offers convenience to tourists for obtaining information before travel decision they would make (Lai \& Vinh, 2013). Past studies have shown that destination image is often found to be an intermediary factor to explain the effect of using social media on the intention to travel (Baloglu, 2000). Besides the image of a destination that is held in the tourist mind, intention to travel can also be influenced by travel motivation (Chetthamrongchai, 2017; Chu \& Luckanavani, 2018; Zhong, 2012). On this basis, this study aimed to determine the effect of online 
Printed by: serliw@petra.ac.id. Printing is for personal, private use only. No part of this book may be reproduced or transmitted without publisher's prior permission. Violators will be prosecuted.

promotion and travel motivation, both directly and through the mediation of the destination image and intention to travel to eco-tourism destinations in Indonesia.

\section{LITERATURE}

Before tourists visit a destination, they would collect information about a destination from various sources of information, both offline and online (Chu \& Luckanavani, 2018). Literature has consistently shown that online promotion has a significant influence on potential tourists' destination preferences and travel intentions (Lai \& Vinh, 2013; So \& Morisson, 2003; Tsai et al., 2017). It offers a more convenient and more comfortable way for tourists to gather information needed by tourists about the destination they want to visit and influence travel intentions. Based on the above discussion, the following hypothesis was proposed:

Hypothesis 1: online promotion has a positive and significant influence on the intention to travel

Travel motivation is an essential factor that influences the intention to travel (Chu \& Luckanavanich, 2018; Chetthamrongchai, 2017; Zhong, 2012). There are two classifications of travel motivation. First, social-psychological motivation is related to the psychological status of individuals. Second, cultural motivation is more directed to the destination (Baloglu, 2000). According to Crompton (1979), social-psychological motives items are escaping from a perceived mundane environment, exploration and evaluation of self, relaxation, prestige, regression, enhancement of kinship relationships, facilitation of social interaction. Cultural motives items are novelty and education. Previous research has revealed that travel motivation consistently had a significant effect on travel intentions (Chu \& Luckanavanich, 2018; Jang et al., 2009; Zhong, 2012). On this basis, the second hypothesis is formulated:

Hypothesis 2: travel motivation has a positive and significant influence on the intention to travel

Destination image is someone's belief, ideas, and impression about destination (Crompton, 1979). Destination image is an important element that influences intention to travel and is often seen as an intermediary between intention to travel with online promotion and travel motivation (Baloglu, 2000; Chen \& Tsai, 2007). Destination image can be divided into two: cognitive image, that is viewed as a set of evaluation that someone remembers when thinking about a destination; and affective image, that is defined as feelings or emotions that is owned by someone about a destination (Agapito et al., 2013). Destination image is an important factor that drives travel intention. It is a tendency felt by tourist to visit a destination within a particular period (Woodside \& Lysonski, 1989). Previous research has consistently shown a significant effect of travel motivation on travel intention through the mediation of the destination image. Based on the preceding discussion, the following hypotheses are formulated as follows:

Hypothesis 3: destination image mediates the effect of online promotion on the intention to travel

Hypothesis 3a: cognitive image mediates the effect of online promotion on the intention to travel

Hypothesis 3b: affective image mediates the effect of online promotion on the intention to travel

Hypothesis 4: destination image mediates the effect of travel motivation on the intention to travel

Hypothesis 4a: cognitive image mediates the effect of travel motivation on the intention to travel

Hypothesis 4b: affective image mediates the effect of travel motivation on the intention to travel

Hypothesis 5: destination image has a significant and positive effect on the intention to travel

Hypothesis 5a: cognitive image has a significant and positive effect on the intention to travel

Hypothesis 5b: affective image has a significant and positive effect on the intention to travel 
Printed by: serliw@ petra.ac.id. Printing is for personal, private use only. No part of this book may be reproduced or transmitted without publisher's prior permission. Violators will be prosecuted.

\section{METHODOLOGY}

A questionnaire-based survey was completed to tourists who would travel to any eco-tourism destinations in Indonesia. A pilot study was undertaken before the survey to ensure that all measurement items were valid and reliable. Applying a purposive sampling technique, a total of 348 questionnaires had been distributed, and out of the total, 319 questionnaires were used. Prior to data analysis employing the above-mentioned statistical techniques, the data-cleaning process was accomplished to test the normality and possible outliers.

\section{RESULT}

\subsection{Findings of participants}

Among the 319 participants, $61.1 \%$ were female, and $38.9 \%$ were male. Half of the participants were between 22 and 26 years old $(50.5 \%)$. Two major groups of university students and employees were dominating at about $62.7 \%$ of total participants. In terms of the travel characteristics, the majority of participants often travel with their family (52.7\%), spent 3 to 6 hours per day on the internet (49.5\%). The most often online platform that is referred to for seeing the information was Instagram (43.3\%), Youtube (21.3\%), and Trip Advisor (15\%). The top three popular eco-tourism destinations in Indonesia among respondents were Mount Bromo (East Java), Komodo National Park (NTT) and Nusa Penida Island (Bali).

\subsection{Hypotheses finding and other findings}

In order to assess the research model and test the proposed hypotheses, PLS path analysis was employed. The PLS path model analysis illustrates that all measures met the commonly accepted threshold for assessing the reliability and validity of the constructs. Figure 1 demonstrates the outcome of the structural model test. It shows that the intention to travel to ecotourism destination is determined by online promotion and destination image. Travel motivation also encourages tourists to have an intention to travel to eco-tourism destinations by being mediated by the image held in tourists' minds about the destination they would like to visit. Based on the PLS bootstrap results, all hypotheses were accepted except hypothesis 2, that is, there is travel motivation did not have a significant influence on intention to travel to eco-tourism destination $(\mathrm{t}$-values $=1.593<\mathrm{t}$-table $=1.96)$.

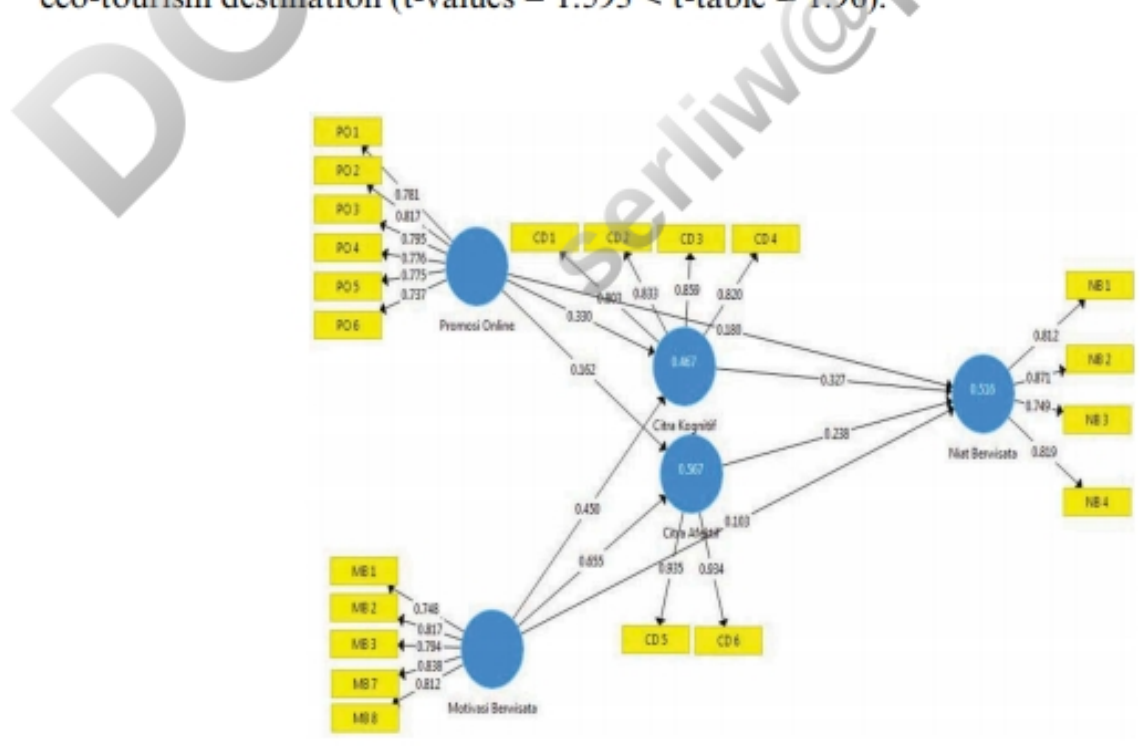

Figure 1. Path diagram of the research model. 
Printed by: serliw@petra.ac.id. Printing is for personal, private use only. No part of this book may be reproduced or transmitted without publisher's prior permission. Violators will be prosecuted.

\section{DISCUSSION AND SUGGESTIONS}

\subsection{Discussion}

This study revealed that the more online promotions that are carried out, the higher intention to travel that are owned by tourists because online promotion is the effective tool in driving tourists have the intention to travel to eco-tourism destinations. In addition, the more online promotion conducted by eco-tourism destinations will make tourists have a good destination image and increase the intention to travel. Positive destination image owned by tourists will encourage travel motivation. The most appealing result revealed in this study is that travel motivation does not affect the intention of traveling. That is, having the motivation to travel alone is not enough to push tourists having the intention of travelling to eco-tourism destinations, especially when visiting eco-tourism destinations that are less popular among the tourists. In this situation, tourists need a good image of the destination where the image of this destination can be obtained through online promotions carried out by eco-tourism destinations in Indonesia.

\subsection{Suggestions}

Government and relevant tourism authorities, both local and national need to enhance their efforts to promote eco-tourism destinations because there is a possibility that tourists are not familiar yet with eco-tourism destinations in Indonesia. Provision of information on the website and social media still needs to be improved, such as paying more attention to the information provided to make it more accurate and complete. The examined variables in this current research can be adopted for future research in different types of special interest tourism developed in Indonesia or other geographical regions. Further study could be undertaken by including travel constraints and travel perceived risk variables in the measurement since these two variables could also determine travel intentions.

\section{REFERENCES}

Agapito, D., Valle, P., \& Mendes, J. 2013. The cognitive-affective-conative model of destination image. Journal of Travel \& Tourism Marketing 30(5), 471-481.

Baloglu, S. 2000. A path analytic model of visitation intention involving information sources, socio-psychological motivations, and destination image. Journal of Travel \& Tourism Marketing 8(3), 81-90.

Chen, C. F., \& Tsai, D. 2007. How destination image and evaluative factors affect behavioral intentions. Tourism Management, 28(4), 1115-1122.

Chetthamrongchai, P. 2017. The influence of travel motivation, information sources and tourism crisis on tourists' destination image. Journal of Tourism Hospitality, 6(2), 1-6.

Chu, C. P., \& Luckanavani, S. 2018. The influence of social media use and travel motivation on the perceived destination image and travel intention to taiwan of the Thai people. International Journal of Arts and Commerce, 7(3), 22-36.

Crompton, J. L. 1979. Motivations for pleasure vacations. Annals of Tourism Research 6(4): 408-424.

Donohoe, H. M., \& Needham, R. D. (2008). Internet-based eco-tourism marketing: Evaluating Canadian sensitivity to eco-tourism tenets. Journal of Ecotourism, 7(1), 15-43.

Jang et al. 2009. Affect, travel motivation, and travel intention: A senior market. Journal of Hospitality \& Tourism Research, 33(1), 51-73.

Lai, W. H., \& Vinh, N. Q. 2013. Online promotion and its influence on destination awareness and loyalty in the tourism industry. Journal Advances in Management \& Applied Economics, 3(3), 15-30.

Mandiri, A. (2016). Tourism promotion through Wonderful Indonesia. Retrieved March, 9th 2019 from https://www.suara.com/lifestyle/2016/04/02/194548/promosi-pariwisata-melalui-wonderful-indonesia.

Ramdjal, M. 2018. Rural tourism and eco-tourism + community based tourism approach. Retrieved April, 19th 2019 from https://www.kompasiana.com/masrura/5bf337ae43322f231d185b93/desa-wisatapendekatan-pengembangan-berbasis-partisipasi-community-based-tourism?page=all\#

So, A. \& Morrison, A. M. 2003. Destination marketing organizations' website users and nonusers: A comparison of actual visits and revisit intentions. Journal Information Technology \& Tourism, 6, 129-139. 
Printed by: serliw@ petra.ac.id. Printing is for personal, private use only. No part of this book may be reproduced or transmitted without publisher's prior permission. Violators will be prosecuted.

Tsai, Y. C., Chu, C. M., \& Kobori, K. 2017. The influence of video clips on travel intention and destination image. International Journal of Arts and Commerce, 6(1), 37-55.

Weaver D.B. 2001. Eco-tourism as mass tourism: Contradiction or reality? Cornell Hotel and Restaurant Administration Quarterly, 42(2), 104-112.

Zhong. C. 2012. A structural analysis of the motivation, familiarity, constraints, image, and travel intention of Chinese non-visitors to Thailand. Retrieved March, $15^{\text {th }} 2019$ from http://www.assumptionjour nal.au.edu/index.php/AU-GSB/article/view/478 